\title{
REINDUSTRIALIZATION AND NATIONAL ECONOMIC MODELS
}

\author{
S. Konstantinova*, A. Konarev \\ Faculty of Economics, University of Food Technologies - Plovdiv, Bulgaria
}

\begin{abstract}
The authors elaborate on the role and importance of the industry for sustainable development of Bulgarian society. After definition of industrial production scope, analyzed were the reasons for the GDP share reduction in the industrial capacity of Bulgaria and the EU Member States, known as "Deindustrialization". The necessity of promoting the industry development and increase its relative share in the GDP, called "Reindustrialization", is substantiated. Successful examples of the global economy are presented. Proposed are national industrial production specific policies and development tools. According to the authors, Reindustrialization and related industrial policy will not be successful if conducted separately. They must be part of a new national economic strategy. The thesis that Bulgaria needs its own economic and social development model is substantiated. In this regard are presented the main economic and social model features of the American and European models. By revealing the European model inconsistency, the authors propose basic national model parameters and policies.
\end{abstract}

Key words: industry, model, politics, economics, development

\section{INTRODUCTION}

Reindustrialization is an issue of strategic importance for the development of Bulgaria. In our previous studies (1) we have substantiated the role and importance of the industry for sustainable development of the Bulgarian society. Reindustrialization is defined (2) as a process of increase in the relative share of the industry in the structure of the Gross Domestic Product (GDP) through the establishment of new and the expansion of existing competitive industrial processes on the basis of smart specialization. The European Union has introduced a "Strategy for revival of the industry for the purpose of stable economic growth" (Renaissance of Industry for a Sustainable Europe - RISE) (3) which encourages innovation with the purpose of a third industrial revolution. The European Commissioner for Industry, Antonio Tajani, is the author of the proposal for increase of the share of industry in the establishment of the GDP in the EU from $15.1 \%$ to $20 \%$ by the end of 2020 (2). The reason for this is the reduction

\footnotetext{
${ }^{*}$ Correspondence to: Assoc. Prof. Snezhinka Konstantinova Stoyanova, PhD, Faculty of Economics, University of Food Technologies Plovdiv, Bulgaria, 4002 Plovdiv, P.B. 27, Bulgaria, Cell Phone: $\quad+359878384372, \quad$ E-mail: sks_ko@abv.bg
}

in the share of industry in Europe in the establishment of the gross added value since 2000. The only exception is Germany, where this share is constant. The analysis of the data for the years of crisis (2008-2013) shows that there is a persistent downward trend in the share of industry in the GDP of the EU - from $21 \%$ before the crisis to $15.1 \%$ for 2013 , despite the presence of significant differences between the individual Member States $(4,5)$.

The relative share of the industry in the GDP of Bulgaria is hovering around $25 \%$. This relatively high share of the industry in the establishment of the GDP in comparison with the EU average $(15 \%)$ gives grounds to a number of economists and politicians to oppose the idea of reindustrialization. The analysis shows that a significant part of these rates is for the mining industry. Moreover, a large part of the manufacturing industry is specialized in labor-intensive industries (textiles, clothing, leather goods, shoes, etc.) and in capital-intensive industries (cement, refined petroleum products, non-metallic mineral products, etc.). The relative share of mechanical engineering decreases continuously. The high-tech goods in Bulgarian export constitute only $3 \%$ of its volume while the average indicator for the EU Member States is $16 \%$ (over 5 times). 
KONSTANTINOVA S., et al.

In another scientific report (6) is proved that the problem of financing of industrial companies is one of the major problems for the development of the industry of the country. The business model of the foreign banks that are dominant in the Bulgarian banking market is based on the low risk concept of mass retail banking, in the center of which are the attraction of household savings and the provision of consumer and mortgage loans for purchase of housing. These leading activities of banks are supplemented with a relatively limited amount of short-term financing of small and medium-sized companies, primarily in the form of working capital loans. The loans for investment needs, which are generally long-term, are a rare exception in the activities of these banks.

The Bulgarian-owned banks (7) are small, poorly capitalized, with limited access to international money and capital markets. They usually attract household savings with the help of unreasonably high interest rates on deposits, which sharply reduces their profit margins and hampers the internal accumulation of capital. Some of them exist mainly thanks to the deposited in them free budget funds and free liquidity of state companies. Under these conditions it is very difficult, almost impossible, to take long-term loans for investment purposes. The industry, especially high-tech industry, requires significant investment in tangible capital and in fixed assets, which without the bank loans are almost impossible.

\section{PURPOSE}

In order to help solve this problem in our researches we offer to be established two new banks as specialized lenders of industrial projects:

1. Industrial Bank AD, which credits mainly the high technologies, the pharmaceutical industry and competitive existing companies from the so-called "historical industry";

2. Bank BioHrani AD, which primarily lends to companies in the food processing industry, the production and the processing of organic food, biotechnology and three segments of tourism with potential for added value: SPA, wellness and balneal tourism.

\section{MODELS AND DISCUSSION}

These banks should be created on the basis of fundamentally new models:

1. New capital model:

- $51 \%$ state capital, in order to ensure targeted use of credit resources;

- $49 \%$ private capital, in order to ensure efficiency and transparency by the minority shareholders, who choose independent directors in corporate management bodies.
- Specialized lending (for more accurate risk assessment);

- A limited number of banking products (investment and working capital).

We suggest that these banks launch a public issue of shares - Initial Public Offering (IPO), as 510 million of the shares of each bank should be purchased by the state and the rest 490 million by private investors. In this situation, each of the banks will have an initial capital of at least BGN 1 billion (at issue price of the share equal to its nominal value).

The state capital necessary for the establishment of these banks can be taken from the capital of the current state bank, called "Bulgarian Development Bank" AD (8), which has more than BGN 1.70 billion. According to our assessment this bank works extremely inefficiently.

The proposal includes the establishment of two guarantee funds to the two new banks, and the Bulgarian Development Bank AD to remain operational as a banking group, focused on lending to the sector of micro-, small and medium enterprises.

The continuation of the research in this field have led us to two main conclusions:

1. Bulgaria does not need new industrial policy! The country needs new economic and social model!

2. At present in the country there is no force that is able to solve this national problem: formation and implementation of own model of development of Bulgaria.

Although, for some economists and politicians the need of one's own model is not in the spirit of the European integration, Bulgaria needs its own economic model on the following specific features:

- The poorest country in the EU;

- High real unemployment;

- Uncontrollable "leakage" of working population and increasing immigration;

- Severe demographic crisis;

- Low standard of living, accompanied by deepening social stratification;

- Insufficient potential and capital in the "triangle of knowledge";

- Increasing "leakage" of talent (over $80 \%$ of Bulgarians with scientific degree "Doctor" (work abroad);

- Depopulation of entire areas, mainly in mountainous, border and inaccessible areas and the decline of farming there, etc.; 
These problems are purely Bulgarian and solving them requires a sharp increase of the role and the importance of politics and an active state intervention in the economy and public life.

We believe that in this moment there is no internal force capable to solve this national problem, and our only real hope is in the European Commission and the EU as a whole. The attempts by the World Bank and the International Monetary Fund in the early 90s led to tragic results. But what should this model be?

Studies of different models (1) reveal the richness of specific opportunities. The US economic and social model is consistent with the perceptions and the attitudes of the overwhelming majority of the American society to the basic problems of human existence. In the USA, as a country of conquerors and settlers, have been established highly individual values, ways and forms of behavior, resting on personal initiative and personal responsibility, which are also reflected in the corporate culture and market behavior of companies. In the American society dominates the image of the strong individual, who takes his destiny in his hands and provides his existence exclusively with his individual efforts.

The regulation of the US economy is carried out in most part by the securities market, by the organized market, by the stock exchange and the unorganized market. The US is the largest importer of financial capital in the world. This explains the extremely high external debt of the country. So, it is no coincidence that financial and stock analysts are among the most ardent supporters of the US economic and social model. The easy access to capital markets allows for higher entrepreneurial activity occurring in the first place in the continuous incorporation of companies. One portion of the new companies manage to grow into large economic entities, others are sold to larger existing companies, third terminate their existence due to low competitiveness.

Large multinational companies headquartered in the United States generally have highly developed departments for research and development activities that enable them to continuously introduce new products in mass production. The US labor market is characterized by considerable flexibility and mobility. The employment contracts are shortterm; the long-term employment relations are rare. In line with the development of the conjuncture, the companies respectively start cutting jobs.
The European economic and social model is based on regulated market economy, which aims to achieve a compromise and coexistence of the competition mechanism with the mechanism of social redistribution. In Europe there is a strong, developed over the centuries, sense of solidarity, which is institutionalized, i.e. it found reflection in a number of institutions that in one degree or another act as a corrective or limit the negative effects on the functioning of the free market economy. Solidarity contributes to stronger cohesion in society and limitation of the potential of social tensions.

In distinction from the American model, the role of the securities market, the stock exchange and the OTC trading as a regulator of economic life is relatively limited, although in recent decades, and especially with the affirmation of the neoliberal economic thinking among most of the political elite in Europe, it begins to play an increasingly important role. The bank credit plays a dominant role in the financing of European companies. Its relative share in the countries of the Eurozone is $46 \%$, as in some countries, such as Italy, it is $65 \%$. In Europe, the role of the venture capital for the set-up of new companies in the field of new products and technologies is almost marginal. The innovation of companies is achieved primarily as a result of in-house research and development activities in the conditions of a strong provision of subventions by the state.

The workforce in Europe is significantly more expensive than in the US. This is due to the shorter average working hours, especially in the services sector, the higher social security contributions paid by employers, the limited opportunities for staff reductions due to the labor legislation favorable to the wage labor. Therefore, the attitude towards the workforce is more careful and caring. On the other hand, the high level of wages in Europe is a strong incentive for innovations with the purpose of reduction of labor costs.

The European economic and social model is not uniform. The French economic model is based on a relatively high degree of dirigisme, on state intervention in the economic life, and last but not least in the form of a policy of protectionism in terms of national financial and industrial capital. In the political rhetoric of France the idea of a strong state and its right to regulate and intervene in the economy still occupies a central place, although in practical terms over the past three decades, it lost its authority. 
The German economic and social model is still considered the most effective among the European models, which manifests itself in the leading role of the German economy in Europe and not only that. What makes this model so successful? In general terms, it is the long-term planning in the implementation of nationwide programs, the priority development of research and development activities and the investments in education, the development of industry at the expense of the financial industry, the high qualification of the workforce and its relatively high flexibility. The chains of value creation in Germany are based on intensive research and development activities. While in most countries, members of the Organization for Economic Cooperation and Development (OECD) (9), the costs of research activities, measured as a percentage of the GDP, decreased for years and in 2009 reached its lowest level, then in Germany these costs increased and amounts to almost $3 \%$ of the GDP.

In the $70 \mathrm{~s}$ and $80 \mathrm{~s}$ of the last century the economic model of the Nordic countries and in the first place of Sweden, drew the attention of politicians and economists as a model of a "third path" between capitalism and socialism. In the early 90s Finland and Sweden, and partly Denmark, were in a serious economic crisis. In the late 90s Denmark was again considered as a successful alternative to the model of the countries of the Anglo-American region. At the beginning of the new millennium there was a talk about Sweden as a country that has successfully overcome its crisis, a country that made the necessary structural reforms and created a new solid base for economic growth and higher living standards. During this time particular attention attracted the Finnish economic and social model. In other words, after a relatively strong economic crisis, the Nordic countries were back among the countries with high economic growth, with innovative power, low unemployment and a developed system of national defense.

For our country the following national patterns are also very interesting:

- The development model of Ireland, which from a small, poor, peripheral country in the 70s became the "Celtic tiger";

- The national model of Finland, which from a poor agrarian country in the 60s, became the country with the highest living standard in the world;

- The national model of Hungary, which is based on long-term development scenarios;
- The national patterns of the Baltic countries (Lithuania, Latvia and Estonia), which have very topical aspects useful for our country, etc.

\section{CONCLUSIONS}

The research conducted so far enables the following conclusions:

1. Bulgaria does not need new industrial policy. Bulgaria needs its own new national economic and social model.

2. Currently, Bulgaria has no internal power, which to establish and implement a national development model. The European Commission and the European Union are the only real force, capable to finance and coordinate such development.

3. From the presented national economic models of particular interest are some of the more successful models of the former centralized economy countries such as Hungary and the Baltic countries.

4. At this stage, our research did not allow us to form the main parameters of a successful national model.

\section{REFERENCES}

1. Konarev, A., et al. White Paper on a new high-tech industrialization. Plovdiv: Atlas Finance, pp. 15-16, 2014.

2. Konarev, A. and S. Konstantinova. Reindustrialization and Smart Specialization of Bulgaria. - In: International conference Times of uncertainty and risks: possibilities and perspectives for development. Plovdiv: UP "Paisii Hilendarski", pp. 359-366, 2014.

3. http://www.europarl.europa.eu/

4. The Republic of Bulgaria. National Reform Programme (2011-2015) Implementing a Strategy "Europe 2020", Sofia, Bulgaria, 2011.

http://ec.europa.eu/europe2020/pdf/nrp/nrp _bulgaria_bg.pdf.

5. http://ec.europa.eu/europe2020

6. Konstantinova, S. Analysis and Modelling of Industrial Companies Cash Flows under Crisis Conditions. In: Scientific Anniversary Scientific Conference whit International Participate, Trakia University, on May 19-20, Stara Zagora, 2015. (in print)

7. Konarev, A. and S. Konstantinova. Reindustrialization and Financial Innovation. Scientific Proceedings. In: $10^{\text {th }}$ International Scientific Conference "Economics and Management of Innovation - Modern Theories and Practices". Varna: Publisher "Largo City", pp. 337-342, 2014.

8. http://www.bbr.bg/

9. http://www.oecd.org/ 